\title{
Two kinds of definites in numeral classifier languages *
}

\author{
Peter Jenks \\ UC Berkeley
}

\begin{abstract}
Numeral classifier languages distinguish definite noun phrases licensed by uniqueness from those licensed by familiarity. Unique definites are expressed by bare nouns or null pronouns, while familiar definites are expressed by indexicals such as demonstrative descriptions or overt pronouns. This generalization parallels the observation by Schwarz (2009) that German distinguishes unique versus familiar or anaphoric definiteness in its article system. The difference between the two kinds of definites can be reduced to the presence of a semantic index in the case of familiar definites. As familiar definites occur in most E-type contexts, including donkey anaphora, and uniqueness definites are not possible in these contexts, these facts provide support to dynamic analyses of E-type anaphora and pose problems for uniqueness-based approaches, such as the theory of Elbourne (2013).
\end{abstract}

Keywords: Definiteness, bare nouns, dynamic semantics, E-type anaphora, donkey anaphora

\section{Introduction}

A longstanding debate in the analysis of definiteness is whether it is better characterized by reference to uniqueness, familiarity, or some mix of the two (Heim 1982, 1990; Kadmon 1990; Roberts 2003). A less popular view is that uniqueness and familiarity are independently necessary to account for separate classes of definite expressions (Birner \& Ward 1994; Poesio \& Viera 1998). While non-unified views of definiteness in English have been viewed skeptically (e.g., Abbott 1999), recent cross-linguistic work has added grist to the mill of the non-uniformity view. For example, Schwarz (2009) demonstrates that German has two semantically distinct definite articles, a weak article licensed by uniqueness and a strong article licensed by familiarity, where the relevant notion of familiarity is what Roberts (2003) calls strong familiarity, licensed by prior mention in a text or conversation.

* I am grateful to the participants of SALT 25 and Florian Schwarz for helpful questions and suggestions. For the Thai data I am indebted to the thoughtful assistance of Vichayapan Bandhaya, Maytas Monsereenusorn, and Ratana Patumwat. For the Mandarin and Cantonese data which are discussed but not included I am grateful to I-Hsuan Chen and Herman Leung. The mistakes, I feel quite confident to say, are all mine. 
In this paper, I show that the realization of definiteness in numeral classifier languages provides further support for the independent necessity of uniqueness and familiarity. The basic generalization is as follows:

(1) In many numeral classifier languages:

a. Unique definites are realized as bare nouns

b. Familiar definites are realized as demonstratives or overt pronouns

While this generalization is exemplified below with Thai, the same facts seem to hold in Mandarin Chinese, Korean (e.g., Lee 1995), and Japanese (e.g., Kurafuji 1999, 2004). The generalization does not extend to numeral classifier languages such as Cantonese and Bangla, which mark definiteness with classifiers (Cheng \& Sybesma 1999; Dayal 2012), or languages such as Yi (Nuosu), which has a definite article (Jiang 2012). While the facts in these latter languages will be different, one must eventually ask what type of definiteness is realized by the relevant markers in these languages as well.

Below I outline four environments which constitute unique definites, mostly following Schwarz (2009). These include larger situation definites, weak definites, immediate situation definites, and some cases of bridging. These environments form a unified class in that they do not require any explicit linguistic antecedent. Environments which are licensed by linguistic antecedents constitute cases of familiar definites. In these environments, which include donkey sentences, bare nouns are prohibited. As bare nouns are licensed by uniqueness, the inability of bare nouns to occur as donkey anaphora raises issues for theories which rely only on uniqueness to achieve out-of-scope binding in donkey sentences (Heim 1990; Elbourne 2013).

My analysis below hews to that of Schwarz (2009) in most respects. While uniqueness definites denote the unique individual in a particular (minimal) situation, anaphoric definites contain an additional semantic argument, a dynamic index. This analysis makes the right predictions in 'pronoun of laziness' contexts, as bare nominals but not indexical expressions receive sloppy interpretations. This final observation is reminiscent of Kurafuji's (1998) finding that Japanese null pronouns prefer sloppy readings in these contexts while overt pronouns only allow strict readings. I show that Kurafuji's generalization follows if the uniqueness versus familiarity distinction described above is mirrored in whether pronouns are covert or overt.

\section{Numeral classifier languages and definiteness}

In the literature on the semantics of nominals in numeral classifier languages, it is easy to find examples such as the following, with bare nouns translated as definites (this and all following examples are from Thai): 
Two kinds of definites in numeral classifier languages

măa kamlay hàw.

dog PROG bark

'The dog is barking.'

Such examples constitute the standard evidence for the claim that bare nouns in these languages can be definite. Such a claim has been made, for example, for Thai (e.g., Piriyawiboon 2010), Mandarin (e.g., Cheng \& Sybesma 1999), Japanese (e.g., Kurafuji 2004), and Korean (e.g., Kim 2005). Most of the cited works treat definiteness as a unified class, and provide simple examples such as (2) to establish this claim. ${ }^{1}$

Interestingly, demonstratives in classifier languages are sometimes claimed to mark definiteness as well (e.g., Chen 2004 for Mandarin; Lee 1995 for Korean). However, the consistency test of Löbner (1985) shows that demonstratives are not translational equivalents of definite articles (Piriyawiboon 2010: 49):

$$
\begin{aligned}
& \text { dèk khon nán noon yùu tèc dèk khon nán mâi.dâi noon yùu. } \\
& \text { child CLF that sleep IMPF but child CLF that NEG sleep IMPF } \\
& \text { 'That child is sleeping but that child is not sleeping.' (cf. \#the) }
\end{aligned}
$$

Putting together the observation that bare nouns can receive definite interpretations and the observation that demonstratives are not translational equivalents of definite articles, the consensus seems to be that "classifier languages do not mark definiteness" (Jiang 2012: p. 15). But many questions remain. What is the nature of the definite interpretation of bare nouns? And in what contexts do demonstratives function as definites?

Enter recent work establishing a robust cross-linguistic contrast between uniqueness and familiarity definites across languages. Observations that some definite articles are anaphoric date back at least to Greenberg 1978, but the distribution of such articles have not been systematically tested in the contexts of most interest to formal semanticists. In this regard, Schwarz (2009) provides a benchmark for future crosslinguistic work on definiteness, demonstrating that whether or not definite articles in German can be contracted with prepositions corresponds to their definite semantics: while unique definite environments require contraction ('weak definites'), familiar definite environments systematically require the full definite article ('strong definites'). More recent work has expanded these observations. For example, Arkoh \& Matthewson (2013) show that the Fante determiner -n $v$ only occurs in familiar environments, with bare nouns occurring in uniqueness contexts (though the latter claim remains implicit in their paper). In addition, Schwarz (2013) identifies several

1 Lee (1995) is an exception in this regard, as he suggests that the generalization which I demonstrate below for Thai holds for Korean, namely, that bare nouns are unique definites and demonstratives noun phrases are anaphoric. Yet his paper lacks the data to clearly establish this generalization. 
other languages with a similar contrast, including Lakhota, which is claimed to have two separate articles for unique versus familiar definites. ${ }^{2}$

Here I demonstrate that the distinction between unique versus familiar definites also accounts for the distribution of bare nouns and definite demonstratives in many numeral classifier languages: bare nouns are licensed by uniqueness, while demonstratives occur in familiar environments. Once the linguistic context is appropriately controlled, this distinction is brought into sharp relief. I conclude that the contrast is hard-wired into the semantics of the relevant nominal expressions: demonstratives occur in anaphoric definite environments, while bare nouns are systematically prohibited in these environments, and demonstratives are prohibited in definite environments licensed by uniqueness. Thus, the uniqueness vs. familiarity contrast is systematically reflected in the nominal morphosyntax of numeral classifier languages.

\section{Bare nouns as unique definites}

There are four distinct uses of bare nouns as definites in numeral classifier languages: larger situation definites, weak definites, immediate situation definites, and part-whole bridging. These uses are labeled unique definite environments by Schwarz (2009), who observes that they only permit weak articles in German. While uniqueness characterizes most of these environments, they are also unified in that in all cases the non-linguistic context suffices to identify the referent of the relevant noun phrase, in contrast with the familiar definites discussed in the following section. Below I introduce the four uniqueness-based uses of bare nouns. After providing examples of bare nouns in each of the four environments below, I discuss the prospects for extending Schwarz's (2009) situation-based analysis to bare nouns.

\subsection{Larger situation definites}

First, bare nouns in numeral classifier languages are used with larger situation definiteness (Hawkins 1978), a category where uniqueness is licensed by general knowledge. For example, the sun, moon, sky, and weather are known to be unique in all real-world contexts, and as such allow bare nouns:

$\frac{\text { duay-can (\#duay nán) sàwàạ mâak. }}{\text { moon (CLF that) bright very }}$

'The moon is very bright.'

2 Uniqueness and familiarity may not even be sufficient to account for the range of definiteness semantics across languages. Barlew (2014) argues that the notion of salience is necessary to account for the distribution of a definite article in Bulu, a Bantu language of Cameroon. 
Two kinds of definites in numeral classifier languages

Likewise, predicates which are known to be unique due to common cultural or social knowledge are translated with bare nouns. For example, once equipped with the knowledge that Thai provinces elect one Senator and two Ministers of Parliament, the following contrast obtains:

sǒo-woว chiay-mày (\#khon nán) gròot mâak.

senator Chiang Mai CLF that angry very

'The/\#That Senator from Chiang Mai is very angry.'

sǒo-sǒo chiay-mày \#(khon nán) gròot mâak.

M.P. Chiang Mai CLF that angry very

'\#The/That M.P. from Chiang Mai is very angry.'

These examples show that demonstrative descriptions are allowed whenever bare nouns are not. When the predicate is not unique, such as 'that M.P. from Chiang Mai,' a demonstrative is possible, but demonstratives are infelicitous when they pick out individuals that are known to be unique. Thus, if a predicate is only true for a single individual regardless of context, it will be translated with a bare noun.

\subsection{Weak definites}

The second use of bare nouns is with weak definites (Poesio 1994; Barker 2005; Carlson, Sussman, Klein \& Tananhaus 2006), illustrated below:

\section{Sùthêep phaa Sǒmchay pay (thîi) rooy-phayabaan}

Su. take So. go to hospital

'Suthep took Somchai to the hospital.'

\# Sùthêep phaa Sŏmchay pay *(thîi) tìk

Su. take So. go to building

'Suthep took Somchai to the building.'

Even if we do not know which hospital Suthep took Somchai to, 'hospital' can be definite in English. On the other hand, 'building' is odd as a definite description out of context. Here, the hospital is a weak defintie in English, and it is translated with a bare noun in numeral classifier languages. Other weak definites include the objects of predicates such as listening to the radio and opening the blinds.

Because they pattern with unique definites, it is surprising that weak definites do not actually require uniqueness. In fact, weak definites are surprising in several other respects as well. Poesio (1994) shows that possessive weak definites are possible in existential sentences, and Carlson et al. (2006) show that weak definites show the same kind of quantificational variability that indefinites do. Weak definites also have a restricted grammatical distribution. They are typically internal arguments, 
and often license preposition omission, both indications that they are somewhat incorporated into the predicate. Schwarz (2014) provides an analysis of weak definites which relies on uniqueness relevant to an event, while Aguilar-Guevara $\&$ Zwarts (2010) argue that weak definites involve reference to kinds. Setting the question of their proper analysis aside, it is important that weak definites pattern reliably with uniqueness definites in classifier languages in requiring bare nouns.

\subsection{Immediate situation definites}

The third environment where definite bare nouns must be used in the relevant classifier languages is in immediate situation definites, another term from Hawkins 1978. Like larger situation definites, immediate situation definites rely on shared knowledge between the speaker and hearer, but this knowledge is specific to a particular situation or context. Consider the following examples:

rót yùu thîi-năi?

car LOC place-which

'Where the car?'

măa kamlay hàw.

dog PROG bark

'The dog is barking.'

Cars and dogs are only unique relative to specific individuals or households, so the use of a bare noun to refer to these entities assumes a certain amount of familiarity with the speaker's circumstances. Provided such familiarity obtains, the bare noun can felicitously be used in these contexts. Immediate situation definites occur constantly in daily life, but used in isolation in a linguistics paper, they rely on the imagination of the reader to evoke a suitable context where there is exactly one relevant individual who satisfies the descriptive content of the noun.

\subsection{Bridging}

The fourth environment where definite bare nouns occur is in some cases of bridging, also called associative anaphora (Hawkins 1978) or inferrables (Prince 1981). Bridging definites are licensed by virtue of their association with a linguistic antecedent, for instance, a possession or authorship relation. Schwarz (2009) shows that only cases of bridging in German pattern licensed by inalienable, part-whole possession pattern as unique definites, while cases of bridging licensed by a producer-product association pattern as familiar/anaphoric definites. ${ }^{3}$ The same pattern obtains in

3 Schwarz reports some variation among specific examples and between speakers. I have not conducted a systematic survey, but the native speakers of numeral classifier languages I have consulted with 
Two kinds of definites in numeral classifier languages

numeral classifier languages, as the examples below demonstrate:

rót khan nán thùuk tamrùat sàkàt phró? mâj.dâj tìt satikəə car CLF that ADV.PAS police intercept because NEG attach sticker wáj thîi thábian (\#baj nán).

keep at license CLF that

'That car was stopped by police because there was no sticker on the license.'

Pool khít wâa kloon bòt nán pró? mâak, mêع-wâa kháw cà

Paul thinks COMP poem CLF that melodious very, although 3P IRR

mâj chôop náktècykloon \#(khon nán).

NEG like poet CLF that

'Paul thinks that poem is beautiful, though he doesn't really like the poet.'

In (11), thábian 'license (plate)' is licensed by virtue of its part-whole relationship with the antecedent rót 'car.' This is an instance of part-whole bridging, and a bare noun is possible for the bridged definite. In contrast, náktè $y k l o o n ~ ' p o e t '$ in (12) is the author of its antecedent kloon 'poem,' and a demonstrative must be used.

Schwarz (2009) offers a perspicuous explanation for why these two instances of bridging pattern differently:

... when considering wholes and their parts, it is clear that there is a containment relationship between the two, which in turn ensures that whenever we are looking at a situation that contains the whole, it will also contain the part. This is not the case for the relationship between products and their producers. A situation containing a book does not generally contain the book's author (p. 54).

So for (11), in any situation where there is a unique car, there will be a unique license plate. Because there is a contextually unique license plate, the bare noun is available. However, poems do not contain poets, so the poet in (12) is not contextually unique.

The demonstrative that is required for the bridged definite in (12) indicates that 'that poet' is an anaphoric definite. This is unexpected because the poet has not been mentioned prior in the discourse, and as we will see in the following section, a prior mention requirement holds for the other cases of anaphoric definiteness. Schwarz presents compelling arguments from German that the 'producers' such as the poet in (12) in producer-product bridging are necessarily relational nouns. On the basis of this generalization, Schwarz argues that the indexical argument of anaphoric definites (see example (20)) is satisfied not by an index which identifies the producer, but rather its relatum, the product. While a complete analysis of producer-product

have relatively clear judgments in these examples. 
bridging is beyond the scope of this paper, the similarity of the different types of bridging in numeral classifier languages to the different types of bridging in German provides compelling evidence that the two phenomena are closely related.

\subsection{Uniqueness and the semantics of bare nouns}

Schwarz (2009) proposes the following interpretation for unique definite articles:

(13) Unique definite articles (Schwarz 2009: 148)

$$
\llbracket \text { the }_{\text {unique }} \rrbracket^{g}=\lambda s_{r} \cdot \lambda P: \exists ! x P(x)\left(s_{r}\right) \cdot \operatorname{lx}\left[P(x)\left(s_{r}\right)\right]
$$

Under such a view, definite articles are functions from a situation and a predicate into the unique individual that satisfies that predicate in that situation (Heim 1990; Cooper 1995; Elbourne 2013). The relevant notion of situation is a technical one: situations are parts of worlds, and can be minimal situations, containing a single individual and their contextually relevant properties (Kratzer 1989, 2007). The domain of noun phrases is restricted by a resource situation $\left(s_{r}\right)$ (Schwarz 2012). Thus, in the immediate situation definites in (9) and (10), the resource situation of the relevant noun phrases contains a single dog or car. In a part-whole bridging example such as (11), because the resource situation contains a single car, we can infer that it contains a single license plate as well.

Schwarz extends his analysis to larger situation uses, drawing a parallel between part-whole bridging and relational larger situation definites like mayor, which introduce arguments (e.g., of Oakland) which entail the existence of a unique referent for their predicate. Globally unique situation definites like the sun and the sky are the easy cases, as they are always unique relative to the actual world, of which every actual situation is a subpart. The environment which does not naturally fall out of Schwartz's analysis is weak definites. Schwarz (2009: 73) suggests that weak definites may be instances of kind reference (Dayal 2004), and that uniqueness is licensed by virtue of the uniqueness of a particular kind.

While the logical form in (13) may capture aspects of the semantics of bare nouns in numeral classifier languages, it is not clear where this meaning comes from. Bare nouns in these languages allow a range of readings outside of unique definite ones, including kind-level and scopeless indefinite readings (e.g., Yang 2001; Piriyawiboon 2010; Jenks 2011). What gives rise to the definite reading? An obvious hypothesis is that the unique definite reading arises from a phonologically silent definite article equivalent to (13) (see Simpson 2005; Wu \& Bodomo 2009). Alternatively, one could attribute the unique definite interpretation to a semantic type-shifting operator (Chierchia 1998; Dayal 2004).

An alternative proposal adopted by a number of recent authors is that definite readings for bare nouns are instances of contextually-restricted kind reference (Dayal 
Two kinds of definites in numeral classifier languages

2011; Jenks 2011; Trinh 2011; Jiang 2012). Under such a view, the bare definite $d o g$ would have the interpretation in (14), where DOG represents the dog kind:

$$
\llbracket \operatorname{dog} \rrbracket^{g}=\lambda s_{r} \cdot \operatorname{DOG}\left(s_{r}\right)
$$

This analysis builds on the proposal that nouns in numeral-classifier languages are kind-referring, and hence that numeral classifiers are needed in order to pull individual atoms from the kinds (Krifka 1995, 2003; Chierchia 1998). As a kind is the largest set of individuals which satisfies a certain property within a world or situation, bare nouns would be expected to have unique definite interpretations.

There are two challenges for this kind-based view of definiteness. The first is that the kind-based analysis above is not presuppositional. Yet bare nouns in opaque contexts such as negation nevertheless allow two readings, one of which seems to include an existence presupposition:

phǒm mâj chôop măa.

I NEG like dog

i. 'I don't like dogs.'

ii. 'I don't like the $\operatorname{dog}(\mathrm{s})$.'

Similarly, Russell's (1905) King of France sentences and their negation induce the same uneasiness in Thai that their English equivalents do:

\section{\# kàsàt faràysèt (mâj) hǔa-láan. \\ king France NEG head-bald}

'The king of France is (not) bald.'

A second challenge faced by a kind-based analysis of definite bare nouns is typological. The four environments for unique definites do not pattern together in all classifier languages. Specifically, Cantonese bare nouns can be used for weak definites and larger situation uses, but not for immediate situation uses or part-whole bridging, which require a bare classifier. ${ }^{4}$ Such a restriction corresponds to a natural boundary in the landscape of uniqueness: while larger situation definites and weak definites can occur in any context, immediate situation definites and part-whole bridging rely on contextually specific domain restrictions. This observation follows once uniqueness definites are further split into two subtypes: general definites, comprised of larger situation uses and weak definites, and specific definites, comprised of immediate situation uses and part-whole bridging. If we take general definites to correspond to instances of kind reference, following Aguilar-Guevara \& Zwarts (2010), then immediate situation uses must involve more than kind reference, and hence the kind-based denotation in (14) is insufficient.

4 These facts are detailed in ongoing work, Jenks 2015. Suggestions to similar effects can be found in Li \& Bisang 2012 and Li 2013. 
In summary, Schwarz's (2009) situation-based analysis of unique definites can be extended to numeral classifier languages with little change, with weak definites being an instance of kind reference. Under such an analysis, the definite interpretation can be attributed to a null determiner or type-shift. Another possibility for analyzing unique definites is to analyze them as instances as kind reference restricted to a particular situation. However, the latter view must account for the ambiguity of bare nouns in opaque contexts and fails to account for further cross-linguistic differences in the distribution of definite bare nouns in numeral classifier languages.

\section{Indexicals as anaphoric definites}

This section surveys environments in which definite descriptions can be used felicitously in a language like English but which cannot be translated with bare nouns in numeral classifier languages. To my knowledge, the existence of such environments has not been previously noted. In these environments, languages like Thai and Mandarin require the use of either a pronoun or a demonstrative. These environments are all discourse anaphoric, or strongly familiar in the terminology of Roberts (2003), meaning that they all make reference back to an explicit linguistic antecedent. ${ }^{5}$ These environments exhibit substantial overlap with the environments for E-type uses of pronouns, including classical cases of donkey anaphora.

\subsection{Indexical definites as E-type anaphora}

The narrative sequence below contains an E-type anaphor, the label given to apparent instances of binding without c-command by Evans (1977, 1980). In numeral classifier languages, these anaphoric contexts require a demonstrative description or pronoun (null or overt) ${ }^{6}$; bare nouns cannot be used in these contexts:

a. miawaan phǒm cəə kàp nákrian khon nị̇. Yesterday 1ST meet with student CLF INDEF

'Yesterday I met a student.'

b. i. (nákrian) khon nán / (kháw) chalàat mâak. student CLF that / 3P clever very

'That student/(s)he was very clever.'

5 The one exception to this generalization is the producer-product bridging examples discussed in the previous section. I will not deal with such cases here, but recall the suggestion by Schwarz (2009) that in such cases the linguistic antecedent is the relatum of the bridged definite.

6 Here and below, both overt and null pronouns are possible. However, null and overt pronouns have different meanings, as has been shown by Kurafuji $(1998,1999)$. See section 4.3 for discussion. 
Two kinds of definites in numeral classifier languages

\section{ii. \# nákrian chalàat mâak. student clever very \\ 'Students are clever.'}

These examples are classic problems for purely quantificational theories of indefinites in that the indefinite seems to bind a pronoun (or demonstrative) beyond its scope. Such examples are among the major motivations for dynamic theories of semantics (Kamp 1981; Heim 1982), in which indefinites assign indices to novel discourse referents, contextually salient individuals which can be referred to by subsequent definite noun phrases, such as definite descriptions and pronouns. In numeral classifier languages, indexical expressions such as pronouns and demonstratives must be used in such discourse anaphoric contexts, providing relatively straightforward support for dynamic approaches. The novel finding is that bare nouns in numeral classifier languages cannot be used as discourse anaphora. ${ }^{7}$ In such an environment, the bare noun is restricted to a generic interpretation.

The restriction on anaphoric bare nouns holds regardless of whether an individual's identity is known. The following examples illustrate this observation (modeled after Elbourne 2005, p. 6):

$$
\text { a. phûu-chaay khon nị khâa Suthêep. }
$$

'A $\operatorname{man}_{i}$ killed Suthep ${ }_{j}$.'

b. i. tamruat sǒysǎy wâa phûu-chaay khon nán / (khăw) dây-ráp police suspect COMP man CLF that / $\overline{\mathrm{P}}$ receive bàat-cèp toon-nán injury time-that 'Police suspect that that $\operatorname{man}_{i} / \mathrm{he}_{i}$ was injured at the time.'

ii. tamruat sǒnsǎy wâa phûu-chaay dây-ráp bàat-cèp toon-nán. police suspect COMP man receive injury time-that 'Police suspect that a $\operatorname{man}_{k}$ was injured at the time.'

As before, indexical definites can be used in such an example, but bare nouns cannot. Interestingly, when a bare noun identical to the antecedent is used in these examples, it implies the existence of a third man distinct from the murderer and Suthep.

7 This claim needs qualification: in longer narratives, it is possible to find a bare noun being used in putatively anaphoric contexts. Such uses typically commence after an individual has been established and it is clear that they are the only individual of the relevant type, i.e., they are unique. While I do not have space to illustrate such cases, I think that they ultimately provide further support for the generalization proposed in this paper in that it is only once uniqueness has been clearly established for a particular noun that the bare noun can be used. My hunch is that these uses are essentially equivalent to proper names in languages like English. 
One possible explanation for why anaphoric bare nouns seem to be impossible in the examples above is that the uniqueness presupposition which is characteristic of bare nominal definites is not met. For example, the indefinite in (17) implies that other students are around, and at least two men are present in (18). However, the same facts hold for anaphora to universal quantifiers, as in the following example:

a. nákrian thúk khon sòsp tòk mî̀awaan.

student every CLF test fail yesterday

'Every student failed the test yesterday.'

b. i. day-nán nákrian phûak nán / (phûak-khăw) kôo-ləəi phì-wăn so student GROUP that / GROUP-3P thus disappointed mâak.

very

'So the students / they were very disappointed.'

ii. day-nán nákrian ko-ləəi phìt-wăy mâak.

so student thus disappointed very

'Students are disappointed.'

Plural anaphora in Thai typically make use of a special plural morpheme $p^{h} \hat{u} a k$, roughly 'group', which can be anaphoric to a universal quantifier, as (19b-i) shows. Yet while a bare noun can freely refer to a plurality, and often does, a bare noun cannot be used as an anaphor to a universal quantifier. This observation defuses the uniqueness-based explanation for the unavailability of anaphoric bare nouns in examples (17) and (18); there is only one contextually relevant group of students in (19), and a bare noun still cannot be used to refer back to this group.

\subsection{The indexical semantics of anaphoric definites}

Schwarz (2009) argues that the semantics of anaphoric definites are identical to the semantics of unique definites with the exception of an additional individual argument position. The additional argument is saturated by an index that picks out a contextually salient discourse referent:

(20) Anaphoric definite articles (Schwarz 2009, p. 260):

$$
\llbracket \text { the }_{\text {anaphoric }} \rrbracket^{g}=\lambda s_{r} . \lambda P . \lambda y: \exists ! x P(x)\left(s_{r}\right) \wedge x=y \cdot l x\left[P(x)\left(s_{r}\right) \wedge x=y\right]
$$

The requirement that familiar definites must take a dynamic index as an argument connects with the observation that the indexical expressions which occur as familiar definites can also be used for direct ostension, in which case pointing serves as the index and its assignment (Roberts 2002). ${ }^{8}$ The presence of an indexical argument on

8 For now, I am treating pronouns and both distal and proximal demonstratives the same, with (20) as 
familiar definites is expected in dynamic approaches, which take E-type anaphora to achieve reference by virtue of an index interpreted relative to an assignment function. The case of a plural anaphor to a universal or proportional quantifier as in (19) can be given a similar analysis, where the plurality which is identified by the domain restriction of the universal quantifier is accessible to subsequent reference.

However, alternative approaches to definiteness eschew the indices which are necessary to make dynamic semantics work (e.g., Elbourne 2013), relying exclusively on situationally-restricted uniqueness. Under such a view, if a situation is small enough, it will only contain that individual which was identified by the earlier expression. Thus, the logical form of the subject of The student was clever, say, as a continuation to the English gloss of (17a) would be the unique students in $s_{1}$, where $s_{1}$ is the situation described in the preceding clause.

However, we have already seen that bare nouns cannot be used anaphorically in these contexts, despite the fact that bare nominal definites are freely allowed in other contexts licensed by uniqueness. This is unexpected for the idea that all definites are fundamentally uniqueness definites. So, I conclude, some definite expressions in numeral classifier languages are inherently indexical, and these are the expressions which occur with familiar or anaphoric uses of definites.

\subsection{Pronouns of laziness}

In the anaphoric contexts above, bare nominals are prohibited, while demonstratives and both overt and null pronouns are available. However, in 'pronoun of laziness' contexts, such as paycheck sentences (Karttunen 1969), null pronouns pattern with bare nouns. More specifically, indexical definites in paycheck sentences pick out the individual referred to by the antecedent, not its sense, while bare nouns and null pronouns pattern together in permitting the covarying or sloppy readings that these sentences are famous for:

a. phûu-chaai thîi fàak நəən-dian wáy kàp mia chalàat kwàa... man REL entrust salary PRFV with wife smart CMPR

'The $\operatorname{man}_{i}$ who entrusts his $i$ paycheck to his wife is smarter than...

b. i. \# phûu-chaai thîi fàak yəən-duan kôon nán/ man wáy kàp man REL entrust paycheck CLF that it PRFV with mia-nóoy]. mistress

... the man who entrusts [that paycheck $]_{j} /$ it $_{j}$ to his mistress.'

their semantic core. They may be further distinguished by additional presuppositions that each lexical item introduces. For example, Roberts (2004) proposes that pronouns include additional salience presuppositions. 
Peter Jenks
ii. phûu-chaai thîi fàak (gəən-dian) wáy kàp mia-nóoy.
man REL entrust salary PRFV LINK mistress
... the $\operatorname{man}_{j}$ who entrusts his ${ }_{j}$ paycheck to his mistress.'

a. pii-níi naayók pen samăachík phûa-Thai.

year-this Prime Minister PRED member pro-Thai.

'This year the prime minister ${ }_{i}$ is a pro-Thai party member.

b. i. \# Pii-nâa khăw/naayók khon nán cà pen samăachík-P.Ch.P. year-next 3P / P. M. CLF that FUT PRED member-democrat

'Next year he ${ }_{i}$ / that P.M. $i$ will be a democratic party member.'

ii. Pii-nâa (naayók) cà pen samăachík-P.Ch.P. year-next Prime Minister FUT PRED member-democrat 'Next year he ${ }_{j}$ will be a democratic party member.'

In these contexts, the same indexical expression which was required in the familiar contexts above must receive a strict interpretation: in (21) the paycheck given to wife and mistress is literally the same paycheck, even if given by a different man, and the Prime Minister who will be in a different party next year in (22) must be the current Prime Minister. In these contexts, however, both bare nouns and null pronouns allow the sloppy interpretation, where the paycheck or Prime Minister changes with the situation.

Kurafuji $(1998,1999)$ observes the same contrast for null versus overt pronouns in Japanese. He analyzes overt pronouns in Japanese as dynamically bound indexicals, consistent with the analysis here, while null pronouns are analyzed as functions from situations or individuals to the maximum individual in that situation, his 'E-type pronouns', following Chierchia $(1992,1995){ }^{9}$

If Japanese patterns with Thai and Mandarin in having two kinds of definite expressions, the different interpretations of null versus overt pronouns identified by Kurafuji are just special cases of unique versus familiar definiteness outlined above. Crucially, the functional semantics that Chierchia $(1992,1995)$ proposes for sloppy interpretations of pronouns and definites can be reduced to the uniquenessbased semantics of bare nouns, functions from situations to the maximal, or unique, individual in the given situation. ${ }^{10}$

So the noun yəən-dian 'salary' and its null pronominal equivalent in (21) are interpreted as functions from situations into the (unique) paycheck in the relevant

9 There is a terminological issue here, as Chierchia and Kurafuji use 'E-type pronoun' in a narrower sense than the original one to refer exclusively to 'pronouns of laziness,' i.e., those pronouns and definite descriptions with functional meanings that result in sloppy readings.

10 A similar proposal has been made for German pronouns, which Grosz \& Patel (To appear) argue are parasitic on the two types of definite articles: personal pronouns are the anaphoric version of German weak articles while demonstrative pronouns are the anaphoric version of German strong articles. 
situation. All that is needed to ensure the sloppy reading in the second clause is that the two occurrences of the noun are interpreted relative to two separate situations. ${ }^{11}$ Similarly, naayók 'Prime Minister' in (22) is interpreted as a function from situations to the unique P.M. in that situation. Because the two clauses are interpreted at different times, hence, different situations, the noun can refer to two distinct individuals. In contrast, the indexical expression must refer to an existing discourse referent. In both examples, the only available discourse referent is the individual introduced in the first clause. As such, using the indexical expression in this environment results in the bizarre strict reading.

One complication is that null pronouns are possible in all E-type environments, including contexts that prohibit bare nouns such as the narrative sequences in section 4.1. To account for the broad availability of null pronouns, Kurafuji proposed that they are ambiguous between indexical and functional interpretations. I can see two ways of accommodating Kurafuji's ambiguity proposal in light of the facts described above. The first is to analyze the apparent ambiguity of null pronouns as syntactic ambiguity between a bare noun or a pronoun which is concealed by NP-ellipsis. This approach avoids positing ambiguity in any lexical expressions, shifting the burden of explanation for ambiguity to the syntactic component. Under such a view, it can be maintained that situational-binding is never used in anaphoric environments.

The second way to account for the wide availability of null pronouns would be to admit that uniqueness definites can be used in familiar contexts, but there are discourse restrictions on bare nouns which do not apply to null pronouns, even though they can both receive functional, uniqueness-based interpretations. Recall that bare nouns qua unique definites are often discourse-new, in the sense of Prince (1992) (though see fn. 7); it may be that there is a novelty condition on bare nominal definites akin to the one proposed for indefinites by Heim (1982).

\subsection{Donkey sentences}

We turn last to donkey anaphora (Geach 1962). As in the other cases of E-type anaphora, donkey anaphora seem to be bound by an earlier indefinite despite failing to occur in its scope. But donkey anaphora are distinguished from the earlier cases of E-type anaphora in that they receive covarying interpretations relative to a ccommanding quantifier. In numeral classifier languages, donkey anaphora pattern as familiar definites, and can only be realized as indexical expressions:

11 One interesting argument for this kind of semantics is that the two occurrences of the noun can have different interpretations with respect to plurality. Chierchia (1995: 115) notes that this is a signature property of 'E-type pronouns' (pronouns of laziness). Thus, the truth of example (21) is not affected by how many paychecks the two men give to their wives or mistresses. As bare nouns in classifier languages are number-neutral, this follows directly. 
[chaawnaa thúk khon thîi mii khwaai tua nịn $\quad$ ] tii khwaai tua nán farmer every CLF that have buffalo CLF INDEF hit buffalo CLF that $/ ?$ ? $(\text { man })_{1}$ $/$ it

'Every farmer that has a buffalo hits it.'

(24) [chaawnaa thúk khon thîi mii khwaai tua nị $]_{1}$ ] tii khwaai *1/gen farmer every CLF that have buffalo CLF INDEF hit buffalo

'Every rice farmer that has a buffalo hits buffalo.' (a generic claim)

When bare nouns can felicitously occur in the position of a donkey anaphor, they can only receive generic interpretations. While such a generic reading is certainly compatible with each farmer beating his own buffalo, such a state-of-affairs is not entailed by the sentence in (24).

From the perspective of dynamic semantics, the requirement that donkey anaphora be indexical expressions is again as expected. Dynamic theories take donkey anaphora to be bound dynamic indices whose assignment varies along with the c-commanding quantifier. Such theories overcome the lack of c-command in donkey sentences by enriching the semantics of connectives such that the information introduced by the first conjunct can dynamically bind variables in the second (e.g., Groenendijk \& Stokhof 1991; Chierchia 1995).

As before, uniqueness-based theories incorrectly predict that definite bare nouns in classifier languages should be able to occur as donkey anaphora. To see why this is so, consider the situation-based truth conditions for donkey sentences proposed by Elbourne (2013); the donkey anaphor is underlined: ${ }^{12}$

a. Every man who owns a donkey beats the donkey.

b. In every situation $s_{1}$ where a man owns a donkey, there is another situation $s_{2}, s_{2}$ a subpart of $s_{1}$, in which the man in $s_{2}$ beats the unique donkey in $s_{2}$.

Here the heavy lifting is done by the part-whole relationship between situations, entailed by the semantics of the universal quantifier. Because the unique donkey in the main clause is contained in a situation $\left(s_{2}\right)$ which is part of a larger situation $\left(s_{1}\right)$ in which a man owns a donkey, the beaten and owned donkeys must be the same.

However, if the meaning of a definite bare nouns is 'the unique $P$ in $s$ ', it should allow covarying readings if situation-based binding can give rise to donkey anaphoric interpretations, contrary to fact. Furthermore, the observation that indexical expressions are required in such examples supports the idea that donkey anaphora are interpreted with the aid of semantic indices. ${ }^{13}$

12 I have simplified Elbourne's analysis for purposes of space. I hope I have not misrepresented that analysis in so doing.

13 See Schlenker 2011 for related facts and arguments from donkey anaphora in signed languages. 
Two kinds of definites in numeral classifier languages

It is worth mentioning that donkey sentences involving indistinguishable participants — including sage-plant sentences and bishop-sentences (e.g., Heim 1990; Kadmon 1990; Elbourne 2010) — behave as expected on the basis of the generalization above: they require indexical noun phrases and prohibit bare nominals. Of course, it is not surprising that these examples behave as familiar rather than unique definites given that they are the limiting cases for uniqueness theories.

However, some donkey sentences do seem to allow bare nouns as donkey anaphora. In particular, donkey sentences which have been observed to favor weak or existential readings (Chierchia 1995: 63) allow bare nominals:

$$
\begin{aligned}
& \text { [thúk khon thîi mii bàt-khredìt } 1 \text { ] chái bàt } t_{1} /\left({ }^{? ?}\right. \text { man) càay-yəən. } \\
& \text { every CLF:person REL have credit-card use card / it pay }
\end{aligned}
$$

'Everyone who had a credit card used it to pay.'

The underlined donkey anaphor in (27) is weak in the sense that each person only needs to use one credit card for the sentence to be true, even if they have several credit cards in their wallet. Thus, the indefinite and donkey anaphor seem to be bound by a single existential quantifier.

I contend that the bare noun in the second clause of (27) is not actually a donkey anaphor; it is not bound. This is because the truth of this sentence does not depend on whether people pay the bill with their own credit cards. Instead, the truth conditions are closer to the sentence Everyone who had a credit card used a credit card to pay. While people tend to pay with their own credit cards, these sentences allows for the two credit cards to be different.

The same is true for the following case of covariation under part-whole bridging, which are alleged to provide evidence for situation-based binding of uniqueness definites by Schwarz (2009: 174):

$$
\begin{aligned}
& \text { [thúk khon thîi sí bâan } 1 \text { tôjo som lăgkhaa (bâan nán). } \\
& \text { every CLF:person REL buy house must fix roof } \\
& \text { 'Everyone who bought a house had to fix a (the) roof.' }
\end{aligned}
$$

The most natural reading of this example is one where everyone bought houses whose roofs were in need of repair. The roof mentioned in the consequent is related to the house in the antecedent by a part-whole relationship, and as such, it is licensed as a uniqueness definite by virtue of part-whole bridging. However, unless the modifier bâan nán '(of) that house' is included, the sentence allows an unbound reading of 'roof' in which people were required to fix some roof in order to buy a house which was not necessarily beneath the roof they fixed. Note that there is still covariation in this interpretation: each house-buyer fixes a different roof, but there is no binding.

I conclude that indexical expressions are necessary to achieve donkey anaphoric 
interpretations in numeral classifier languages. This conclusion poses problem for the uniqueness-based analysis of Elbourne 2013, which incorrectly predicts that the uniqueness-based bare nouns should be available as donkey anaphora, contrary to fact. This conclusion is somewhat stronger than that of Schwarz (2009), who argues that both dynamic binding and situation-based binding can give rise to covarying interpretations of definites.

\section{Conclusion}

I hope to have shown that the distinction in definite semantics observed by Schwarz (2009) for German articles can be extended to different classes of nominals in numeral classifier languages despite the fact that these languages lack definite articles. While bare nouns are used for unique definites, familiar definites must make use of indexical expressions, including demonstratives and overt pronouns. This generalization was extended to account for the distinction between functional and indexical definites proposed by Chierchia $(1992,1995)$, and offered an explanation for Kurafuji's (1999) observation that null versus overt pronouns have different semantic properties, with null pronouns as the pronominal correlate of bare nouns.

With Schwarz (2009), I conclude that both familiarity and uniqueness are necessary components in an empirically adequate theory of definiteness. In addition, the semantically contentful notion of 'familiarity' might be just discourse anaphoricity, modeled with dynamic indices. Numeral classifier languages provide striking confirmation for a semantics with indices given that the expressions which are used in familiar contexts are the same expressions that can be used for pointing, as in signed languages (Schlenker 2011). Finally, the uniqueness-based approaches to donkey anaphora proposed by Heim (1990) and Elbourne (2013) do not predict the right distribution of definite expressions in these languages. The strongest interpretation of these facts is that covarying interpretations of nominals cannot be achieved by the binding of situation variables in natural language.

\section{References}

Abbott, Barbara. 1999. Support for a unique theory of definiteness. In Tanya Matthews \& Devon Strolovitch (eds.), Semantics and Linguistic Theory (SALT) $9,1-15$.

Aguilar-Guevara, Ana \& Joost Zwarts. 2010. Weak definites and reference to kinds. In Nan Li \& David Lutz (eds.), Semantics and Linguistic Theory (SALT) 20, 179-196.

Arkoh, Ruby \& Lisa Matthewson. 2013. A familiar definite article in Akan. Lingua 123. 1-30. doi:http://dx.doi.org/10.1016/j.lingua.2012.09.012. 
Two kinds of definites in numeral classifier languages

Barker, Chris. 2005. Possessive weak definites. In Ji yung Kim, Yury A. Lander \& Barbara H. Partee (eds.), Possessives and Beyond: Semantics and Synax, Amherst, MA: GLSA Publications.

Barlew, Jefferson. 2014. Salience, uniqueness, and the definite determiner -tè in Bulu. In Todd Snider, Sarah D'Antonio \& Mia Weigand (eds.), Semantics and Linguistic Theory (SALT) 24, 619-639.

Birner, Betty J. \& Gregory Ward. 1994. Uniqueness, familiarity, and the definite article in English. In Berkeley Linguistic Society (BLS) 20, 93-102.

Carlson, Gregory, Rachel Sussman, Natalie Klein \& Michael Tananhaus. 2006. Weak definite noun phrases. In Chris Davis, Amy Rose Deal \& Youri Zabbal (eds.), Northe East Linguistic Society (NELS) 36, 179-196. GLSA.

Chen, Ping. 2004. Identifiability and definiteness in Chinese. Linguistics 42(5). 1129-1184.

Cheng, Lisa L.-S. \& Rint Sybesma. 1999. Bare and not-so-bare nouns and the structure of NP. Linguistic Inquiry 30. 509-542.

Chierchia, Gennaro. 1992. Anaphora and dynamic binding. Linguistics and Philosophy 15. 111-183.

Chierchia, Gennaro. 1995. Dynamics of Meaning. Chicago: University of Chicago Press.

Chierchia, Gennaro. 1998. Reference to kinds across languages. Natural Language Semantics 6. 339-405.

Cooper, Robin. 1995. The role of situations in generalized quantifiers. In Shalom Lappin (ed.), Handbook of Contemporary Semantic Theory, Malden, MA: Blackwell.

Dayal, V. 2004. Number marking and (in)definiteness in kind terms. Linguistics and Philosophy 27. 393-450.

Dayal, Veneeta. 2011. Bare noun phrases. In Claudia Maienborn, Klaus von Heusinger, \& Paul Portner (eds.), Semantics: An International Handbook of Natural Language Meaning, vol. 2, 1088-1109. Mouton de Gruyter.

Dayal, Veneeta. 2012. Bangla classifiers: Mediating between kinds and objects. Rivista di Linguistica 24(2). 195-226.

Elbourne, Paul. 2010. On bishop sentences. Natural Language Semantics 18. 65-78. Elbourne, Paul. 2013. Definite Descriptions. Oxford: Oxford University Press.

Evans, Gareth. 1977. Pronouns, quantifiers, and relative clauses (I). Canadian Journal of Philosophy 7. 476-536.

Evans, Gareth. 1980. Pronouns. Linguistic Inquiry 11(2). 337-362.

Geach, Peter. 1962. Reference and Generality. Ithaca, NY: Cornell University Press. Greenberg, Joseph H. 1978. Generalizations about numeral systems. In Joseph H. Greenberg (ed.), Universals of Human Language Volume 3: Word Structure, 249-297. Stanford, CA: Stanford University Press. 
Groenendijk, Jeroen \& Martin Stokhof. 1991. Dynamic predicate logic. Linguistics and Philosophy 14. 39-100.

Grosz, Patrick \& Pritty Patel. To appear. Revisiting pronominal typology. Linguistic Inquiry .

Hawkins, John A. 1978. Definiteness and Indefiniteness: A Study in Reference and Grammaticality Prediction. London: Croon Helm.

Heim, Irene. 1982. The Semantics of Definite and Indefinite Noun Phrases: University of Massachusetts, Amherst, PhD dissertation.

Heim, Irene. 1990. E-type pronouns and donkey anaphora. Linguistics and Philosophy 13. 137-177.

Jenks, Peter. 2011. The Hidden Structure of Thai Noun Phrases: Harvard University, $\mathrm{PhD}$ dissertation.

Jenks, Peter. 2015. Patterns of definiteness without articles. Ms., UC Berkeley.

Jiang, Li. 2012. Nominal Arguments and Language Variation: Harvard University, PhD dissertation.

Kadmon, Nirit. 1990. Uniqueness. Linguistics and Philosophy 13. 273-324.

Kamp, Hans. 1981. A theory of truth and semantic representation. In J. A. G. Groenendijk, T. M. V. Janssen \& M. J. B. Stokhof (eds.), Formal Methods in the Study of Language, Amsterdam: Mathematical Centre.

Karttunen, Lauri. 1969. Pronouns and variables. In Robert I. Binnick, Alice Davison, Georgia M. Green \& Jerry L. Morgan (eds.), Chicago Linguistics Society (CLS) 6, 108-115. Chicago: Department of Linguistics, University of Chicago.

Kim, Chonghyuck. 2005. The Korean Plural Marker tul and its Implications: University of Delaware, PhD dissertation.

Kratzer, Angelika. 1989. An investigation of the lumps of thought. Linguistics and Philosophy 12.607-653.

Kratzer, Angelika. 2007. Situations in natural language semantics. In E. N. Zalta (ed.), Stanford Encyclopedia of Philosophy, CSLI.

Krifka, Manfred. 1995. Common nouns: A contrastive analysis of Chinese and English. In Gregory N. Carlson \& Francis Jeffry Pelletier (eds.), The Generic Book, 393-411. Chicago, IL: The University of Chicago Press, Chicago.

Krifka, Manfred. 2003. Bare NPs: Kind-referring, indefinites, both, or neither? In Robert B. Young \& Yuping Zhou (eds.), Semantics and Linguistic Theory (SALT) 13, 180-203.

Kurafuji, Takeo. 1998. Dynamic binding and the E-type strategy: Evidence from Japanese. In Devon Strolovitch \& Aaron Lawson (eds.), Semantics and Linguistic Theory (SALT) 8, 129-144.

Kurafuji, Takeo. 1999. Japanese Pronouns in Dynamic Semantics: The Null/Overt Contrast: Rutgers University, PhD dissertation.

Kurafuji, Takeo. 2004. Plural morphemes, definiteness, and the notion of semantic 
Two kinds of definites in numeral classifier languages

parameter. Language and Linguistics 5(1). 211-242.

Lee, Chungmin. 1995. Definiteness and specificity. Linguistics in the Morning Calm (Selected papers from SICOL-1992) 3. 663-677.

Li, XuPing. 2013. Numeral Classifiers in Chinese: The Syntax-Semantics Interface. Berlin: Walter de Gruyter.

Li, XuPing \& Walter Bisang. 2012. Classifiers in Sinitic languages: From individuation to definiteness-marking. Lingua 122. 335-355.

Löbner, Sebastian. 1985. Definites. Journal of Semantics 4. 279-326.

Piriyawiboon, Nattaya. 2010. Classifiers and Determiner-less Languages: The Case of Thai: University of Toronto, PhD dissertation.

Poesio, Massimo. 1994. Weak definites. In Mandy Harvey \& Lynn Santelmann (eds.), Proceedings of Semantics and Linguistic Theory (SALT) 4, 282-299. Cornell University Press.

Poesio, Massimo \& Renata Viera. 1998. A corpus-based investigation of definite description use. Computational Linguistics 24. 183-216.

Prince, Ellen F. 1981. Toward a taxonomy of given/new information. In Peter Cole (ed.), Radical Pragmatics, Academic Press.

Prince, Ellen F. 1992. The ZPG letter: Subjects, definiteness, and information-status. In Sandra Thompson \& William Mann (eds.), Discourse Description: Diverse Analyses of a Fundraising Text, 295-325. Amsterdam: John Benjamins.

Roberts, Craige. 2002. Demonstratives as definites. In Kees van Deemter \& Rodger Kibble (eds.), Information Sharing: Reference and Presupposition in Language Generation and Interpretation, 89-136. Stanford, CA: CSLI.

Roberts, Craige. 2003. Uniqueness in definite noun phrases. Linguistics and Philosophy 26. 287-350.

Roberts, Craige. 2004. Pronouns as definites. In Marga Reimer \& Anne Bezuidenhout (eds.), Descriptions and Beyond, 503-543. Oxford: Oxford University Press.

Russell, Bertrand. 1905. On denoting. Mind 14. 479-493.

Schlenker, Philippe. 2011. Donkey anaphora: the view from sign language (ASL and LSF). Linguistics and Philosophy 34. 341-395.

Schwarz, Florian. 2009. Two Types of Definites in Natural Language: University of Massachusetts, Amherst, PhD dissertation.

Schwarz, Florian. 2012. Situation pronouns in Determiner Phrases. Natural Language Semantics 20. 431-475.

Schwarz, Florian. 2013. Two kinds of definites cross-linguistically. Language and Linguistics Compass 7(10). 534-559.

Schwarz, Florian. 2014. How weak and how definite are weak definites? In Ana Aguilar-Guevara, Bert Le Bruyn \& Joost Zwarts (eds.), Weak Referentiality, 213-235. Amsterdam: John Benjamins. 
Simpson, A. 2005. Classifiers and DP structure in Southeast Asia. In Guglielmo Cinque \& Richard Kayne (eds.), The Oxford Handbook of Comparative Syntax, 806-838. Oxford University Press.

Trinh, Tue. 2011. Nominal reference in two classifier languages. In Ingo Reich (ed.), Sinn und Bedeutung 15, 629-644.

$\mathrm{Wu}$, Yicheng $\&$ Adams Bodomo. 2009. Classifiers $\neq$ determiners. Linguistic Inquiry 40. 487-503.

Yang, Rong. 2001. Common Nouns, Classifiers, and Quantification in Chinese: Rutgers University, $\mathrm{PhD}$ dissertation.

Peter Jenks

1203 Dwinelle Hall

UC Berkeley

Berkeley, CA 94720-2650

jenks@berkeley.edu 